Araştırma Makalesi - Research Article

\title{
Açısal Duruş Kontrolü Destekli Özgün bir Dinamik Pencere Yaklaşımı
}

\author{
Suat KARAKAYA ${ }^{1 *}$, Hasan OCAK ${ }^{2}$
}

Geliş / Received: 18/03/2020

Revize / Revised: 05/05/2020

Kabul / Accepted: 16/05/2020

ÖZ

$\mathrm{Bu}$ çalışmada mobil robot sistemleri için hareket planlama probleminde sıklıkla uygulanan Dinamik Pencere Yaklaşımı (DWA) metoduna bir açısal son duruş kontrolü önerilmiştir. Standart uygulamada bir başlangıç ve hedef konumu arasında yol planlama işlevi gören metot hedef konumu için bir açısal duruş kontrolü veya noktasal stabilizasyon sağlamamaktadır. Literatürdeki bu boşluğu doldurmak için çalışılan harita üzerinde bir "sanal garaj” tanımlanarak nihai hedefe yakınsadıkça değişen, adaptif bir yörünge takip prosedürü tanımlanmış, nihai konumda sistemin belli bir duruş açısında konumlanması sağlanmıştır. Yapılan testler sonucunda hesaplanan açısal duruş hataları tatmin edici sonuçlar elde edildiğini göstermiştir.

Anahtar Kelimeler - Dinamik Yol Planlama, Pozisyon Kontrolü, Dinamik Pencere Yaklaşımı.

\footnotetext{
1*Sorumlu yazar iletişim: suatronik@gmail.com (https://orcid.org/0000-0002-3082-0304)

Mekatronik Mühendisliği, Kocaeli Üniversitesi, İzmit 41001, Mühendislik Fakültesi A blok, Umuttepe, Kocaeli 2̇lletişim: hocak@kocaeli.edu.tr (https://orcid.org/0000-0002-9539-6583)

Mekatronik Mühendisliği, Kocaeli Üniversitesi, İzmit 41001, Mühendislik Fakültesi A blok, Umuttepe, Kocaeli
} 


\title{
A Novel Dynamic Window Approach Supported by Posture Control
}

\begin{abstract}
In this study, a final posture control method is proposed to the Dynamic Window Approach (DWA) which is frequently used in the motion planning problem for mobile robot systems. In common DWA applications, the method that performs the path planning task between a start and target position does not provide an angular posture control or point stabilization for the target position. In order to solve this problem in the literature, a "virtual garage" was defined on the map, and an adaptive trajectory tracking procedure that varies as the robot converged to the target pose was defined, and the system was positioned at a certain heading angle in the target position. The angular posture errors calculated as a result of the tests proved that satisfactory results were obtained.
\end{abstract}




\section{GİRIŞ}

Hareket planlama, robotun başlangıç konumu ile hedef konumunu birbirine geometrik olarak bağlayan, kabul edilebilir bir güvenlik düzeyinde planlanmış yörüngelerin hesaplanmasıdır. Kinematik ve dinamik kısıtlara bağlı olarak oldukça zengin bir literatüre sahip olan hareket planlama teknikleri, en temel seviyede iki ana bölüme ayrılabilir: global ve lokal hareket planlama yöntemleri.

Global hareket planlama yöntemleri engellerle ilgili ön bilgileri kullanır ve engel unsurları içemeyen alan içindeki (serbest uzay) başlangıç konumu ile hedef konumu arasında yörüngeler oluşturur. Bu yöntemlerde en temel varsayım, engellerin statik olması ve sensör verileri ile çalışma zamanı içerisinde haritanın değişmemesidir. Hücre ayrıştırma yaklaşımı (cell decomposition) [1], rastgele ağaçlar yöntemi (RRT) [2, 3], potansiyel alan (PF) yöntemi [4], olasılıksal yol haritası (PRM) metodu [5] bu sınıfta yer alır. Engel yerleşim planının doğruluğu bu yaklaşımların performansını doğrudan etkilemektedir. Ortam yerleşim planı ve kinematik modelin karmaşıklı̆̆ algoritmanın işlem süresini dramatik biçimde yükseltmektedir. Gerçek zaman uygulamalarında donanımsal gereksinimler üst düzeydedir.

Ortam ve robot hareketi belirsizse; sonuç olarak, herhangi bir küresel hareket planı engellerden sakınma açısından gerçekçi bir uygulama olmamaktadır. Lokal hareket planlama yöntemleri, çevresel sensör bilgileri ve hedef konumunu kullanarak robot manevralarını değiştirmeye odaklanır. Bu yöntemler ile kontrol edilen sistemler hedef noktasına doğru yönelirken engel konfigürasyonunu özyineli olarak algılar ve bunlardan kaçınmak için gerekli aksiyonları gerçekleştirir. Global planlayıcılara göre en temel avantajları düşük hesaplama karmaşıklığıdır, çünkü bu yöntemler çevre hakkındaki bilgilerin sadece kısıtlı bir bölümünü kullanır. Lokal hareket planlama yöntemleri kendi sınıfında yönelim tabanlı (directional) ve hız uzay (velocity-space) yöntemleri olmak üzere iki türe ayrılır [6]. Yönlü yaklaşımlar engelsiz navigasyon için uygun robot istikamet açısını hesaplar.

Yönelim tabanlı yaklaşımlar, uygulandıkları sistemin kinematik kısıtları dahilinde anlık oryantasyon açısını hesaplar. Bu açısal pozisyonu sağlamak için ekstra hız kontrolü uygulanır ve navigasyon problemi kapalı çevrim bir kontrol sistemi olarak ele alınır. Vektörel alan histogramı (VFH) [7] ve açıklık takip metodu (FGM) [8] yönelim tabanlı hareket planlama yöntemlerine örnek olarak verilebilir.

Hız uzay yöntemleri güvenli navigasyon gerçekleştirmek için sistemlerin dinamik özelliklerini göz önünde bulundurur. Birim zamanda ulaşılabilecek hız ve ivme limitleri temel alınarak modele uygun kısmi yörüngeler oluşturan doğrusal ve açısal hız komutları üretmektedirler. Timed-elastic-band (TEB) [9], lattice planlayıcı [10] ve Dinamik Pencere Yaklaşımı (DWA) [11, 12] bu sınıfta bulunan yöntemlerden en yaygın kullanılanlarıdır. Bu yöntemler bir optimizasyon fonksiyonunu çözümleyerek en düşük maliyetli hız verilerini optimal çözüm olarak sunmaktadır. Sistemin nihai duruş açısının kontrolü (nokta stabilizasyonu) problemi de optimizasyon fonksiyonunun bir bileşeni olarak değerlendirildiğinde bu durum gerçek zamanlı uygulamalar için ekstra bir işlem yükü getirmektedir. Oluşan ek işlem maliyetleri, sistemin dinamik sınırlarının altında bir hızda çalışmasına neden olabilmektedir.

Bu çalışmada açısal pozisyon kontrolü optimizasyon sürecinin dışında tutularak düşük işlem maliyetine sahip geometrik bir çözüm sunulmuştur. Sanal garaj olarak isimlendirilen metot, nihai hedefe belli bir eşik değeri kadar yaklaşan mobil robot sisteminin statik bir referans yörüngeyi takip etmesi prensibine dayanmaktadır. Makalenin düzeni şu biçimdedir: 2. Bölümde DWA metodunun teorik arka planı verilmiştir. 3. Bölümde açısal duruş kontrolü ve referans yol planlama açıklanmıştır. 4. Bölümde holonomik kısıtlara sahip bir model üzerinde açısal duruş kontrolünün uygulama çıktıları sunulmuştur. Bu bölümde aynı zamanda çalışmanın ilgili araştırmacılar tarafından ileri aşamalara taşınması için öngörülen iyileştirmeler tartışılmaktadır

\section{DWA METODU}

Dinamik pencere yaklaşımı (Dynamic Window Approach-DWA), mobil robot dinamik kısıtlarını dikkate alarak belli bir zaman periyodu dâhilinde, belli bir çözünürlükte, robot kütlesinin sahip olabileceği ivme için belirli hız aralıklarını ve dolaylı olarak bu hızlara erişildiğinde elde edilecek kısmi yörüngeleri sağlamaktadır. Bu hesaplamaları, merkezi robotun anlık konumu olan bir pencere sınırlarında gerçekleştirir. Bu pencere içerisinde çarpışmaya neden olacak açısal ve doğrusal hız bileşenleri filtrelenerek, kalan hız çiftleri 
arasında optimal hız bileşenlerini hesaplanır. Bu aşamada bir maliyet fonksiyonu tanımlanmaktadır. Maliyet fonksiyonu robotun hızını, en yakın engelle olan uzaklığını, lokal hedefe olan yakınlığı ve izlenen yörüngeye olan en kısa mesafeyi içeren bir formdadır. Bu fonksiyonu maksimum yapan açısal ve doğrusal hız çiftleri optimal olarak belirlemek için kullanılmaktadır. Mobil robot ile eş merkezli olarak tanımlanan lokal pencere, global harita üzerinde robotun sonraki adımlarda bulunduğu konuma bağlı olarak yer değiştirmektedir. Yöntemle ilgili işlem adımlarını sözel ifadelerle gösteren figür kod Şekil 1'de verilmiştir.

Tanımlı bir zaman periyodunda belli hızlarda robotun ilerlemesi durumunda çarpışma meydana gelip gelmeyeceği kontrol edilerek, eğer çarpışma söz konusu ise ilgili hız çiftlerinin filtrelenmesi sağlanmaktadır. Planlanan çarpışmasız alt yörüngeler robotun holonomik kısıtlarından dolayı bir yay formunda oluşmaktadır. Bu yay görünümlü kısmi yörüngelerin uç noktalarının lokal hedefe yakınlığı, yörüngeyi oluşturan ayrık noktalara olan engel uzaklıkları ve uç noktalarının harici olarak planlanan referans yörüngeye olan yakınlıkları skorlanarak en uygun alt yörünge belirlenir [13]. Bu aşamaları kapsayan maliyet fonksiyonu Denklem 1'de verilmiştir.

1. Robot kontrol uzayını ayrı zamanda örnekle $\left(d_{x}, d_{y}, d_{\theta}\right)$.

2. Örneklenen her hız için, ilgili hız belli kısa bir süre uygulanırsa oluşacak yörüngeyi elde etmek için robotun mevcut durumundan ileriye doğru simülasyon gerçekleştir.

3. Engel yakınlık, hedefe yakınlık, global yörüngeye yakınlık ve hı gibi özellikleri içeren bir metrik kullanarak ileri simülasyondan kaynaklanan her bir yörüngeyi değerlendir (skor tayini). Engellerle çarpışmaya neden olan yörüngeleri filtrele.

4. En yüksek skor alan yörüngeyi seç ve ilgili açısal ve doğrusal hız bileşenlerini mobil robot kontrol birimine gönder.

5. Global hedefe ulaşana kadar işlemleri tekrarla.

Şekil 1. DWA işlem adımları

$$
f_{c}=k_{g} \times g+k_{t} \times t+k_{b} \times b
$$

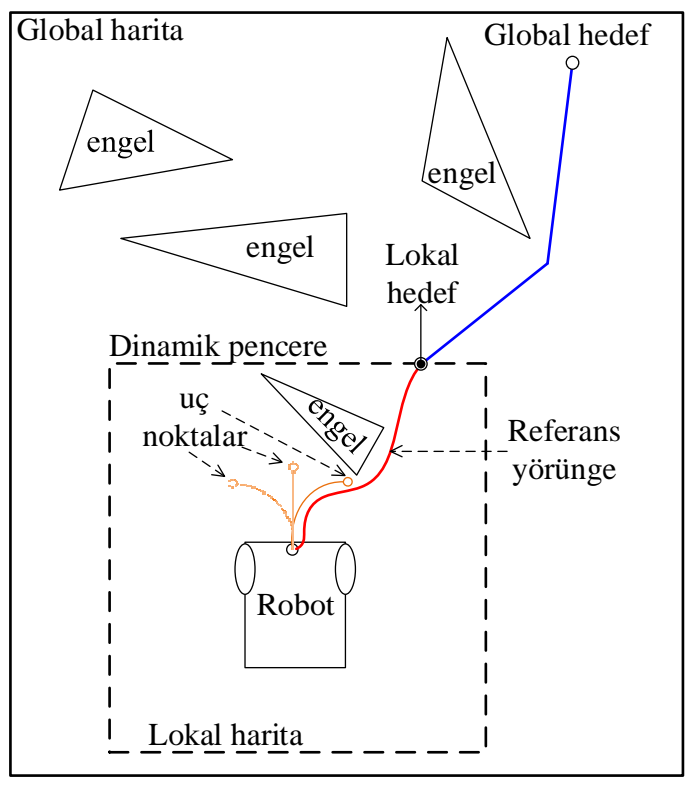

Şekil 2. DWA yol planlayıcı şeması 


\begin{tabular}{|c|c|c|}
\hline & $\begin{array}{l}\text { BŞEÜ Fen Bilimleri Dergisi } \\
7(1), 184-200,2020\end{array}$ & $\begin{array}{r}\text { BSEU Journal of Science } \\
\text { DOI: } 10.35193 / \text { bseufbd. } 705765\end{array}$ \\
\hline U & & 8-7575 (http://dergipark.gov.tr/bseufbd) \\
\hline
\end{tabular}

Verilen maliyet fonksiyonunda $g$ lokal hedef ile kısmi alt yörüngelerin uç noktaları arası uzaklık, $t$ alternatif yörüngelerin bitiş noktalarının global yörüngeye olan minimum uzaklığı, $b$ alternatif yörüngelere en yakın engelin uzaklığını gösteren parametrelerdir. Bu parametrelere ağırlık veren katsayılar ise sırasıyla $k_{g}$, $k_{t}, k_{b}$ ile verilmiştir.

Bu fonksiyonu maksimum yapan açısal ve doğrusal hız büyüklükleri optimal olarak kabul edilmektedir. Lokal bölgedeki engelleri tarayabilen sensörler ile donatılan robot, yerel pencere içerisinde hesaplanan optimal hız kontrol çifti uygulanarak hareket ettirilir. Bu varsayımlar altında tasarlanan DWA yol planlayıcısına ait şematik bir tanım Şekil 2'de gösterilmektedir.

\section{AÇISAL DURUŞ KONTROLÜ VE REFERANS YOL PLANLAMA}

Dinamik pencere içerisinde referans yol planlama aşamasında işlem süreleri gözetildiğinde hücre ayıklama tabanlı yaklaşımlar ve bu dönüşümlere uygulanan lokal tarama çözümleri yaygın olarak kullanılmaktadır. Önerilen yöntemde, hücre mesafe dönüşüm matrisi Dijkstra [14] yöntemi ile elde edilmiş, optimal yörünge oluşturmak için ise lokal pencere haritasında, gradient-descent [15] algoritması uygulanmıştır. Bu işlemler tüm harita üzerinde gerçekleştirilmediği için işlem maliyeti gerçek zamanlı uygulamalar için oldukça kabul edilebilir seviyelerdedir. Pencere boyutu robot için tanımlanan dinamik özelliklerle kısıtlıdır ve bir alan tarayıcı donanımı ya da engel profili ile ilgili görsel bir geri besleme zorunluluğu vardır. Pencere boyutu ve lokal penceredeki engel profili işlem yükü ile doğrudan ilgilidir.

Standart uygulamaya ek olarak, DWA metodu için hedef konumunda açısal kontrol yapılmasına olanak tanıyan bir yaklaşım önerilmiştir. Hedef konumunda istenilen açıya ve robot parametrelerine bağlı olarak sanal bir garaj tanımlanarak robotun düşük işlem maliyeti ile hedef konumuna istenilen açısal pozisyonda konumlanması sağlanmıştır. Açısal duruş kontrolü için global hedefe belli bir Öklid uzaklığı kadar yaklaşılması durumunda, harita üzerinde sanal bir garaj tanımlanarak, robotun bu sanal garaja istenen açıda yerleşmesini sağlayan statik yörünge planlanır ve yörünge takibi prosedürü uygulanır. Lokal yol üzerinde hareket eden mobil robot, dinamik bir engelle karşılaşması veya mevcut engelin ortadan kalkması durumunda güncellenen lokal yolu izlemeye devam etmektedir.

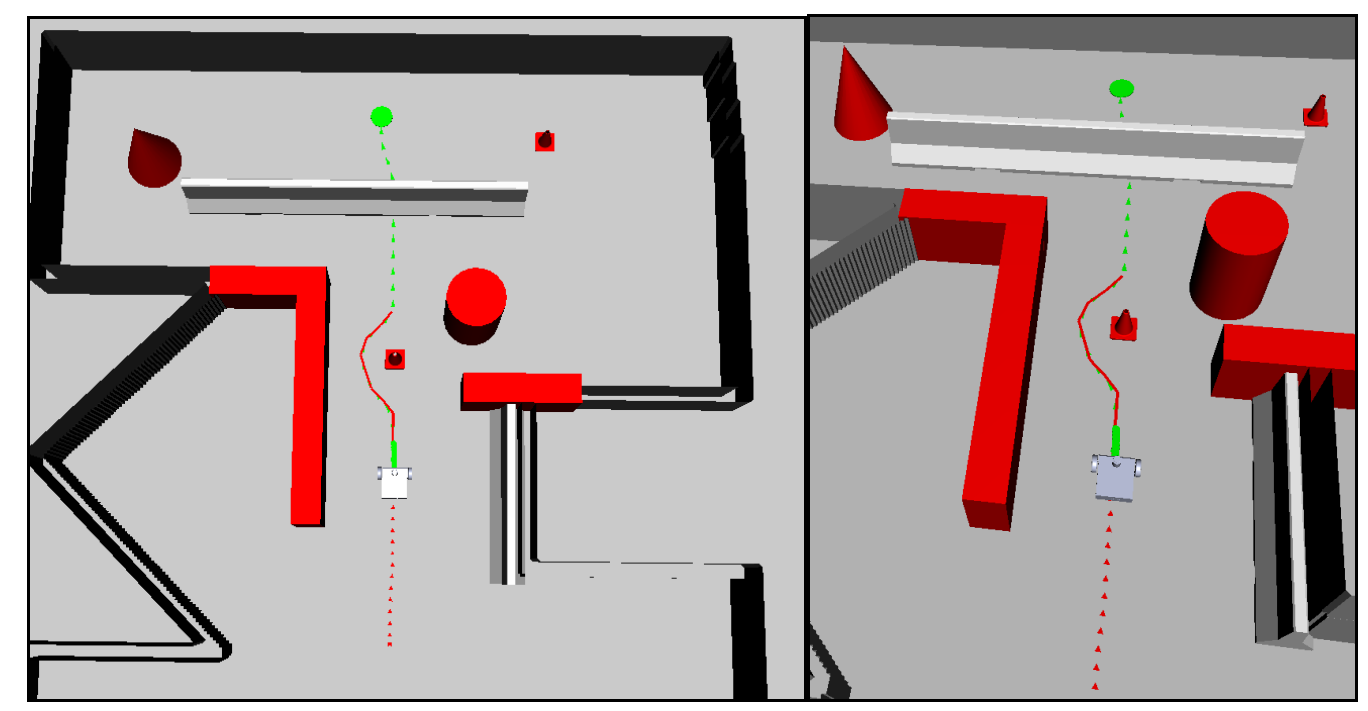

Şekil 3. Örnek bir lokal yörünge ve anlık 3D simülatör görüntüleri

Önerilen yöntemin planlama çıktıları, diferansiyel sürüş modeline sahip gerçek bir mobil robotun 3D MATLAB mobil robot simülatörü aracılığı ile modellenmesi ve gerçek sistemden alınan verilerin uzak bir iş istasyonu üzerinden okunması ile elde edilmiştir. Çalışılan koridor ve laboratuvar krokileri aynı simülatörde 3 
boyutlu olarak modellenebilmektedir. Fiziksel robot ve uzak istasyondaki iş akışı eş zamanlı olarak gerçekleştirilmektedir. Uzak masaüstünde takip edilen sanal robota ve iç mekân haritasına ait bulgular sunulmaktadır. Söz konusu modelleme ortamının geçerlilik ve güvenirlik testleri ilgili referansta sunulmaktadır [16]. Fiziksel robot, çalışma haritaları ve modelleme ortamı ile ilgili detaylı bilgiler deneysel sonuçlar bölümünde verilmektedir. 2D lazer tarayıcı, 3D engel tanımlama ve sık kullanılan kinematik modelleri sunan yazılımın gerçek zamanlı eşdeğeri olan sistemlerle yüksek seviyede uyumlu olduğu ispatlandığı için bu ortam tercih edilmiştir. Şekil 3 'te verilen örnek senaryo için, Dijkstra algoritması ile elde edilen maliyet matrisi (DT distance transform maliyeti), 1S1 haritası olarak Şekil 4'te verilmiştir. Tarama açısı $270^{\circ}$ alan olan tarayıcı sensörün anlık verisi kullanılarak çıkarılan lokal engel haritası Şekil 5'te verilmiştir. Bu grafik üzerinde engel ölçümleri mavi noktalarla gösterilirken, planlanan lokal yol yeşil renkli yörünge biçiminde görselleştirilmiştir. Şekil 6'da alan tarayıcı (LIDAR) datasını gösteren figürün merkezinde mobil robot (kırmızı dikdörtgen) gösterilmektedir. Bu engel konfigürasyonu ve maliyet haritası neticesinde gradient descent algoritması uygulanarak planlanan yörünge ise yeşil renkle kodlanmıştır.

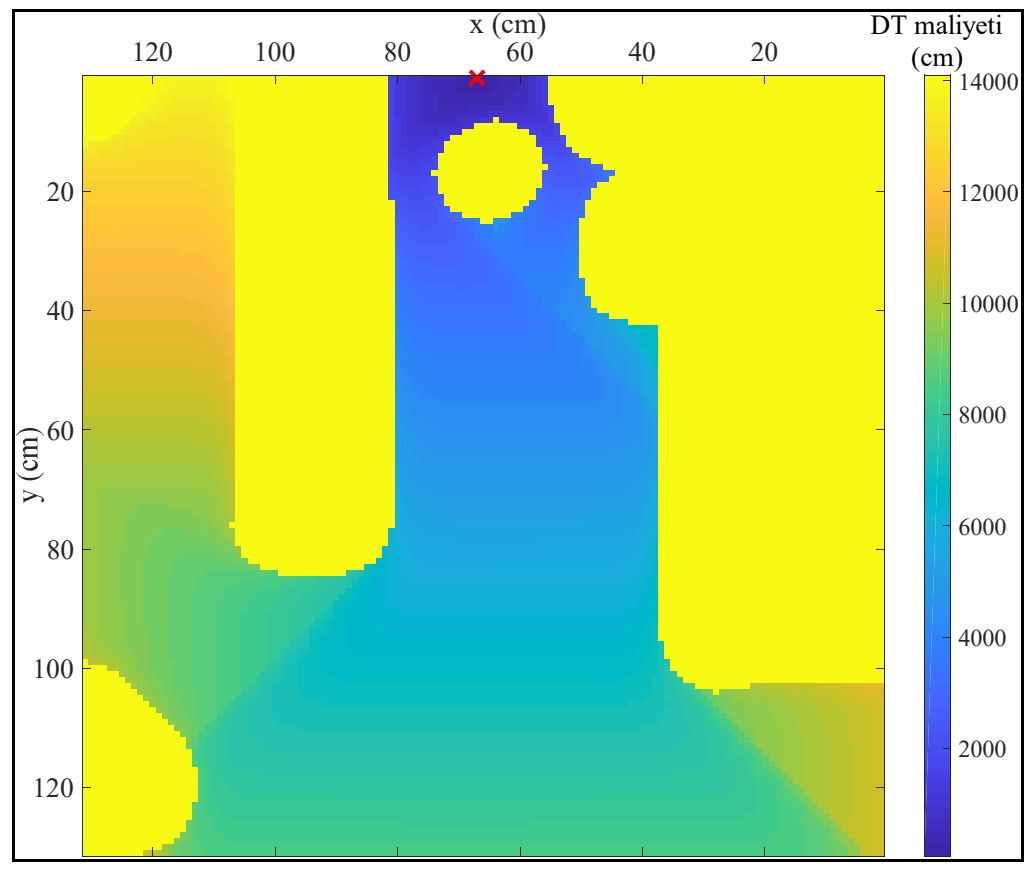

Şekil 4. Lokal bölgedeki maliyet haritası

Robot, benzetim arayüzünde yeşil daire ile gösterilen hedefe ilerlerken anlık olarak lokal pencerede oluşan maliyet haritası Şekil 4'te verilmiştir. Optimal lokal hedef noktası da bu durumda en düşük maliyete sahip nokta olarak belirlenmiştir. Harita üzerinde bu nokta " $x$ ” sembolü ile gösterilmiştir. Şekil 3'te verilen anlık durum için engeller, belli bir güvenlik katsayısı ölçüsünde genişletilerek lokal maliyet haritasına dahil edilmiştir. Lokal bölgedeki engel haritası ise ikili sistemde (binary) tanımlamıştır. Engellerin LIDAR koordinatlarındaki konumları baz alınarak engellenen bölgeler lojik 1, serbest bölgeler lojik 0 olarak tanımlanmıştır. Verilen anlık durum için lokal engel haritası Şekil 5'te verilmiştir. Koyu pikseller serbest, beyaz pikseller engellenmiş bölgeleri göstermektedir. 


\begin{tabular}{|c|c|c|}
\hline & $\begin{array}{l}\text { BŞEÜ Fen Bilimleri Dergisi } \\
7(1), 184-200,2020\end{array}$ & $\begin{array}{r}\text { BSEU Journal of Science } \\
\text { DOI: } 10.35193 / \text { bseufbd. } 705765\end{array}$ \\
\hline U & & 8-7575 (http://dergipark.gov.tr/bseufbd) \\
\hline
\end{tabular}

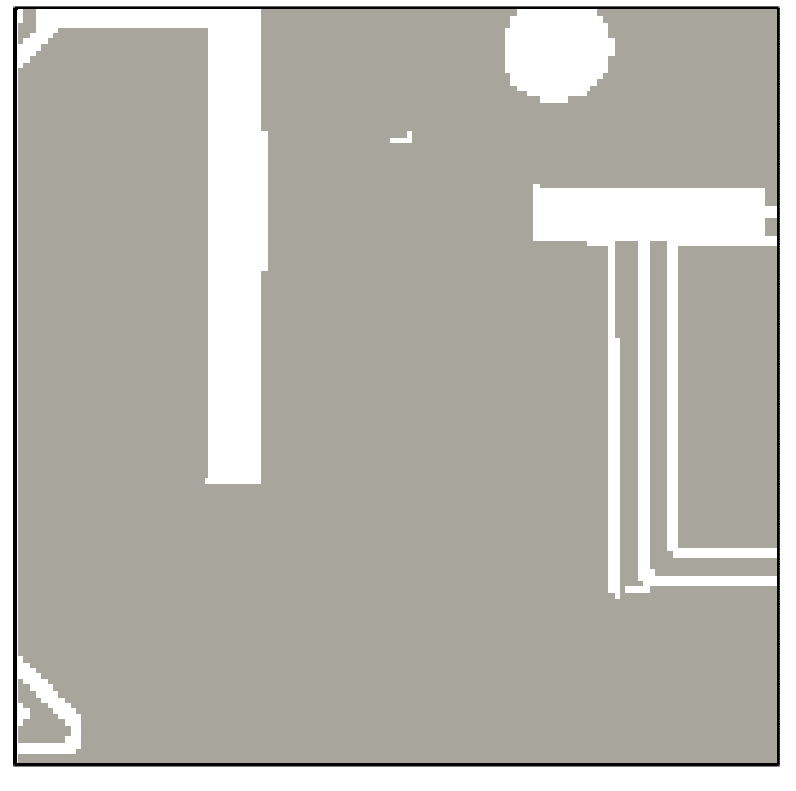

Şekil 5. Lokal bölgedeki engel haritası

Standart DWA yöntemi mobil robotun hedef konumu için tam olarak açısal bir kontrol uygulamamaktadır. Lokal pencere içerisinde global hedef tespit edilip bu noktaya belli bir tolerans bandında yaklaşılması durumunda hedefe ulaşıldığı kabul edilmektedir. Önerilen metot kapsamında sanal garaj (virtual garage) isimli bir yaklaşım ortaya koyularak DWA metodunda bir iyileştirme önerilmiştir. Önerilen yöntemin çalışma prensibi hedef konumunun çevresine robotun boyutlarına bağlı olarak boyutlandırılmış dikdörtgen geometrili, üç kenarı kapalı bir engel yerleştirilmesi temeline dayanır. Bu engel gerçekte olmayan sanal bir engeldir ve duruş açısı, hedef konumunda robotun sahip olması istenilen açıya bağlı olarak belirlenmektedir. Navigasyon sırasında lokal hedef, global hedefe belli bir eşik değerinden daha yakın bir duruma geldiğinde sanal garaj imgesi haritaya eklenerek statik bir yol planlanır. Algoritma yörünge takip moduna alınır ve takip edilen yol engellense dahi alternatif yol planlama işlemi yapılmayarak engelin yoldan çekilmesi beklenir.

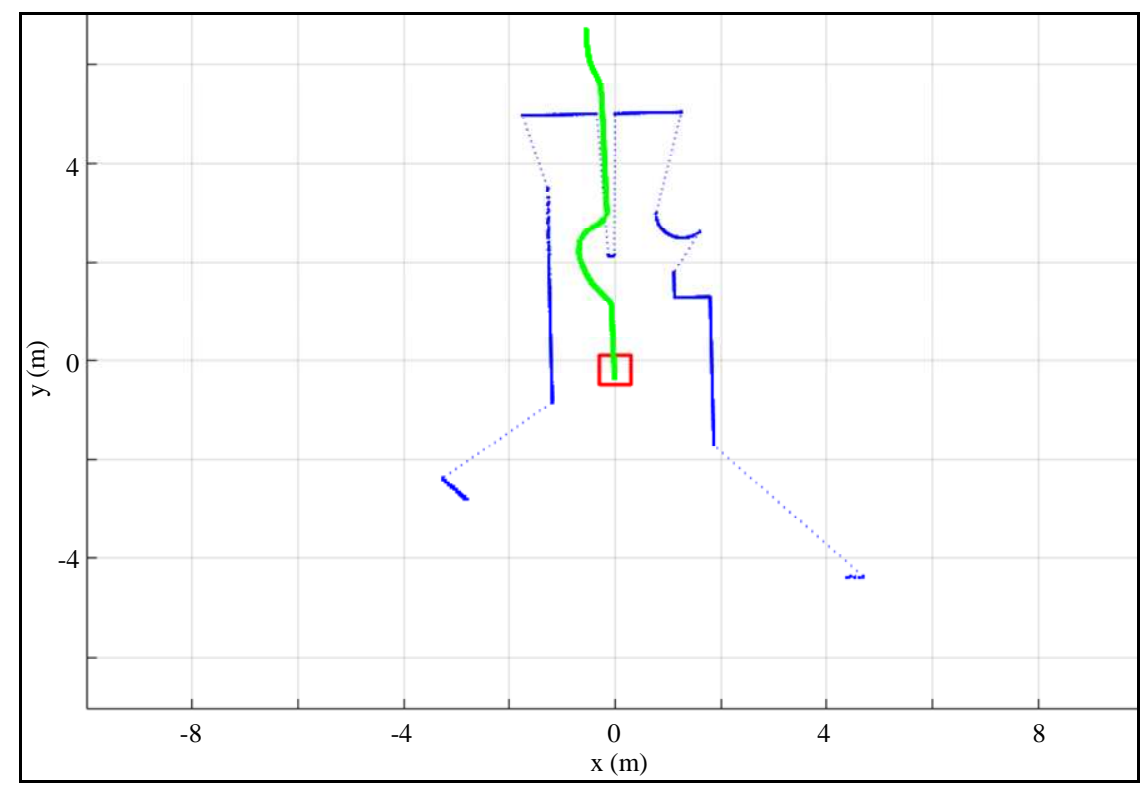

Şekil 6. Lokal bölgedeki LIDAR görüntüsü ve lokal yörünge 
$\mathrm{Bu}$ aşamada lokal hedef $\left(h_{l}\right)$ ile global hedef $\left(h_{g}\right)$ arasındaki Öklid uzaklığı ile orantılı olarak değişen adaptif bir yörünge takip katsayısı (path distance bias : $k_{t}$ ) belirlenir. Bu değer robotun planlanan yol üzerinde hangi uzaklıktaki noktayı lokal hedef olarak belirleyeceğine etki eder. $\left|g_{h} l_{h}\right|$ uzaklık değeri sıfıra yakınsadıkça robot planlanan yolu daha agresif bir şekilde takip etme eğilimi göstermektedir. Bu değer arttıkça Denklem 1'de verilen maliyet fonksiyonunda bulunan $k_{g}$ parametresi (goal distance bias) de kademeli olarak azalt1lır. Burada amaç robotun hedefe ulaşmasını değil, daha ağırlıklı olarak, izlediği yörüngeye sadık kalmasını sağlamaktır. Artırılan ve azaltılan katsayılar referans yörünge takibini pozitif skorlarken, hedefe en kısa yoldan ulaşmayı nötr skorlamaktadır. Garaj imgesi takip aşamasında haritadan kaldırılarak maliyet fonksiyonundaki $k_{b} \times b$ etkisi ortadan kaldırılır. Uygulamaların yapıldığı mobil robot platformu için tanımlı mesafeler ve tanımlı katsayılar Tablo 1'de verilmiştir.

Tablo 1. DWA açısal kontrol yol takip parametresi

\begin{tabular}{cc}
\hline$\left|g_{h} l_{h}\right|(\mathbf{m})$ & $\boldsymbol{k}_{t}(\mathbf{m})$ \\
\hline$\left|g_{\mathrm{h}} l_{\mathrm{h}}\right|>4$ & 2 \\
$2<\left|\mathrm{g}_{\mathrm{h}} \mathrm{l}_{\mathrm{h}}\right| \leq 4$ & 1 \\
$1<\left|\mathrm{g}_{\mathrm{h}} 1_{\mathrm{h}}\right| \leq 2$ & 0,75 \\
$\left|\mathrm{~g}_{\mathrm{h}} \mathrm{l}_{\mathrm{h}}\right| \leq 1$ & 0,3 \\
\hline
\end{tabular}

Benzetim arayüzü üzerinde uygulamanın görsel bir örneği Şekil 7-9 arasında verilmiștir. Global hedef ile lokal hedef arasındaki uzaklığa bağlı olarak robotun yol takip modunda izlediği adımları gösteren benzetim uygulamasının başlangıç durumu Şekil 7'de verilmiştir

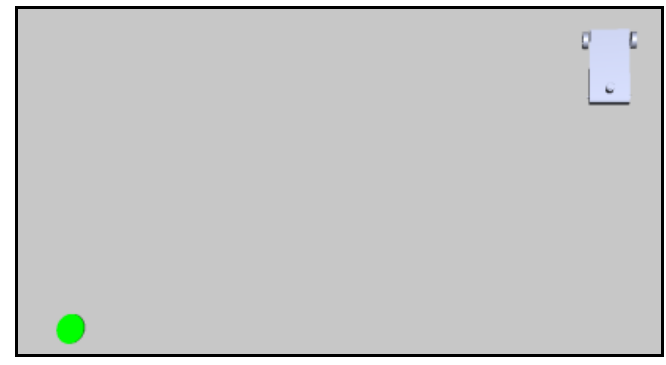

Şekil 7. DWA açısal kontrol: başlangıç konumu

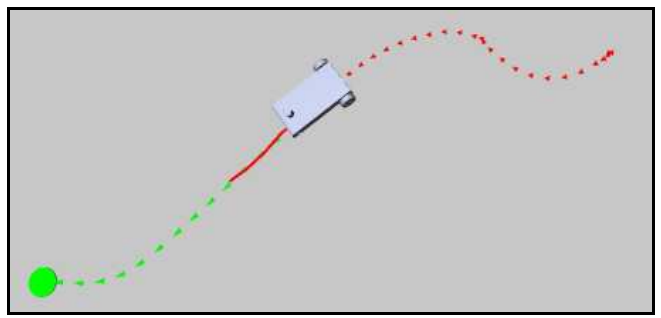

Şekil 8. DWA açısal kontrol: anlık konum 


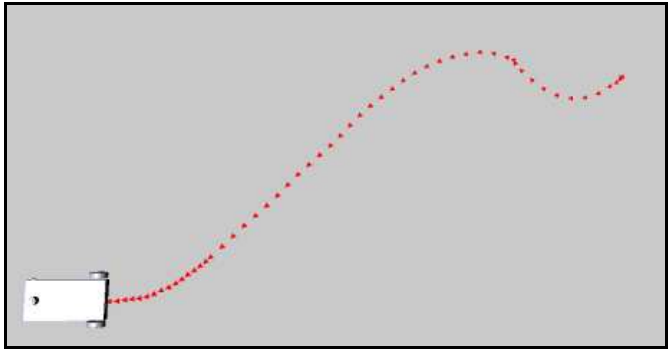

Şekil 9. DWA açısal kontrol: hedef konumu

Robotun başlangıç oryantasyonu $270^{\circ}$, hedef oryantasyonu ise $180^{\circ}$ olarak belirlenmiştir. Hareket başladıktan sonra rasgele bir anlık durum için robotun konumu, planlanan ve izlenen yol durumları Şekil 8'de gösterilmiştir. Yörüngeyi tamamlayan robotun duruş oryantasyonu Şekil 9'da verilmiştir. Robot takip moduna girdikten sonra $\left|g_{h} l_{h}\right|$ uzaklığının değişimine bağlı olarak oluşturulan $k_{t}$ parametrelerinin değerleri Şekil 10'da görülmektedir. Bu değerler Tablo 1'de verilen kriterleri sağlamaktadır. Açısal duruş hatası $1.32^{\circ}$ seviyesinde elde edilmektedir.

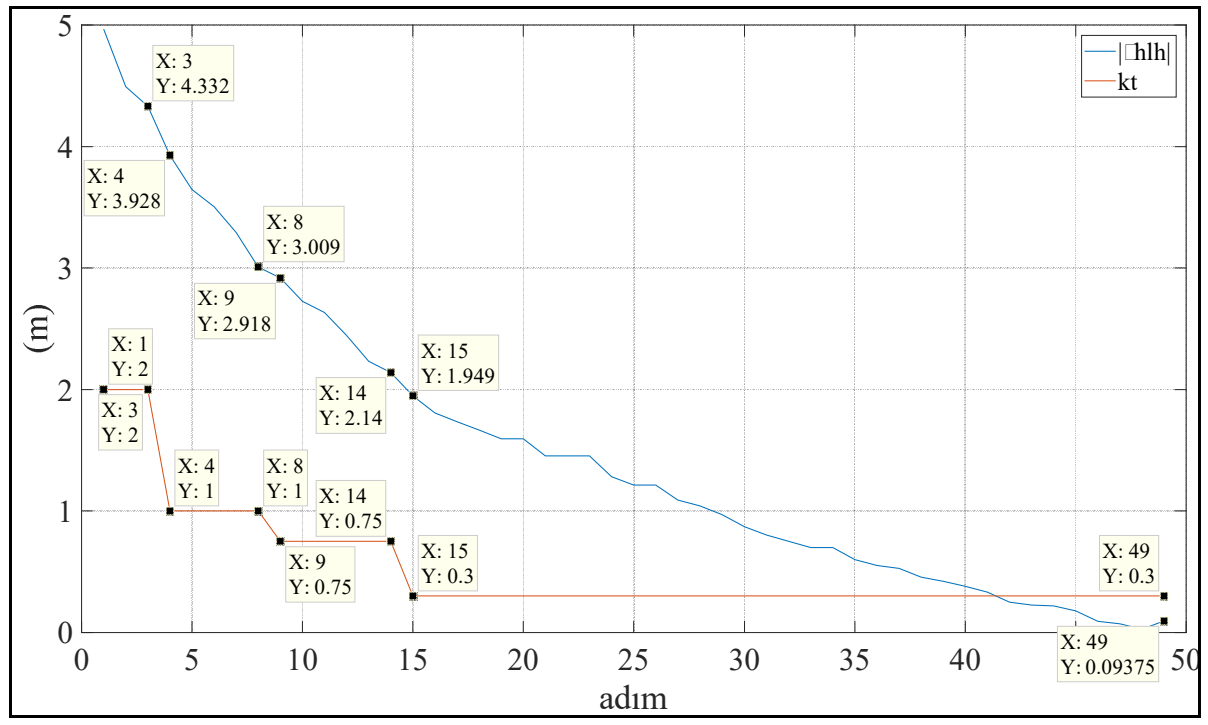

Şekil 10. DWA açısal kontrol: $\left|g_{h} l_{h}\right|-k_{t}$ grafiği

Her işlem adımında lokal hedefin global hedefe yakınsadığı ve buna bağlı olarak robotun takip ettiği yol üzerinde, robot konum merkezine daha yakın bir noktayı lokal hedef olarak belirlediği görülmektedir. Robot global hedefe belli bir eşik değerinden daha yakın olduğu anda ise hedefe ulaşıldığı kabul edilmektedir. Robot boyutlarına bağlı olan bu değer, benzetim modellemesi yapılan robotlar için $5 \mathrm{~cm}$ ve $10 \mathrm{~cm}$ arasında değişmektedir.

\section{DENEYSEL SONUÇLAR}

Deneysel çalışmalar, diferansiyel sürüş kinematik modelinde tasarlanan bir mobil robot üzerinde gerçekleştirilmiştir. Robotun tasarım ve imalat süreci ile ilgili teknik detaylar [17] numaralı kaynakta verilmiştir. Mobil robot bir endüstriyel PC ile desteklenmiş, gerçek zamanlı uygulamaların uzaktan takip edilmesi, görev tanımlanması ve acil müdahale gibi uygulamalar bu PC'ye uzaktan UDP protokolü ile bağlanarak gerçekleştirilmiştir. Dâhili PC ve uzak masaüstü ortak bir kablosuz ağa bağlanarak, geliştirilen uzak bağlantı arayüzü üzerinden tüm kontroller robottan uzak bir istasyon üzerinden gerçekleştirilebilmektedir. Çalışmalar, 
fakültemizin kat koridoru ve laboratuvarlarımızda gerçekleştirilmiştir. Yaklaşık 30x30 $\mathrm{m}^{2}$ alana sahip olan harita üzerinde keyfi başlangıç ve hedef koordinatları belirlenerek robotun final pozisyonunda sahip olduğu duruş açıları kaydedilmiştir. Bu değerler ile referans duruş açıları arasındaki mutlak hata değerleri tablo halinde sunulmuştur.

Uzak istasyon üzerinde 2 boyutlu kat krokisinin 3 boyutlu modeli kullanılarak uzaktan takip sırasında daha gerçekçi bir gözlem yapılması mümkün olmuştur. Elde edilen sanal robot görüntüleri esasen fiziksel robotun koridor ve ofis ortamlarında izlediği yörüngelerin eş zamanlı olarak uzak istasyona aktarılmış görselleridir. Yapılan modellemelerin gerçek dünya koşulları ile benzerliği, modelleme için kullanılan Matlab toolbox yazılımını açıklayan referansta verilmektedir [16]. İlgili referans incelendiğinde gerçek dünya koşulları ile 3 boyutlu modelleme sonucu elde edilen şemaların oldukça tatmin edici seviyelerde benzerlik gösterdiği gözlemlenebilir.

Şekil 11'de uzak masaüstü bağlantısı için geliştirilen arayüz, Şekil 12'de 2 boyutlu kat krokisi, Şekil 13 'te 3 boyutlu olarak modellenen kat haritası sunulmuştur. Mobil robot gerçek ölçüleri ile 3 boyutlu olarak modellenerek uzak istasyonda gerçek zamanlı olarak takip edilmiştir. Şekil 14'te fiziksel robot, Şekil 15'te ise 3 boyutlu modeli verilmiştir. Tüm modellemeler MATLAB robotic-reality toolbox [16] kullanarak gerçekleştirilmiştir.

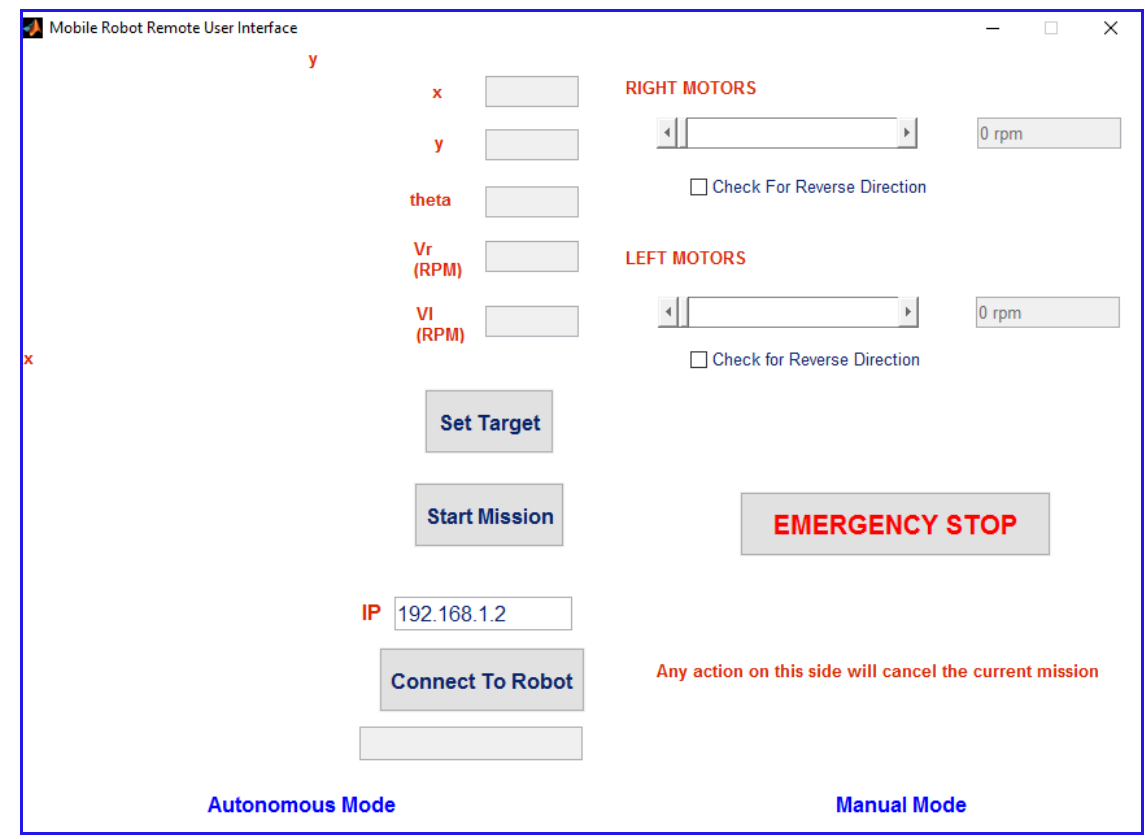

Şekil 11. Fiziksel robot ile bağlantı için tasarlanan uzak masaüstü arayüzü 


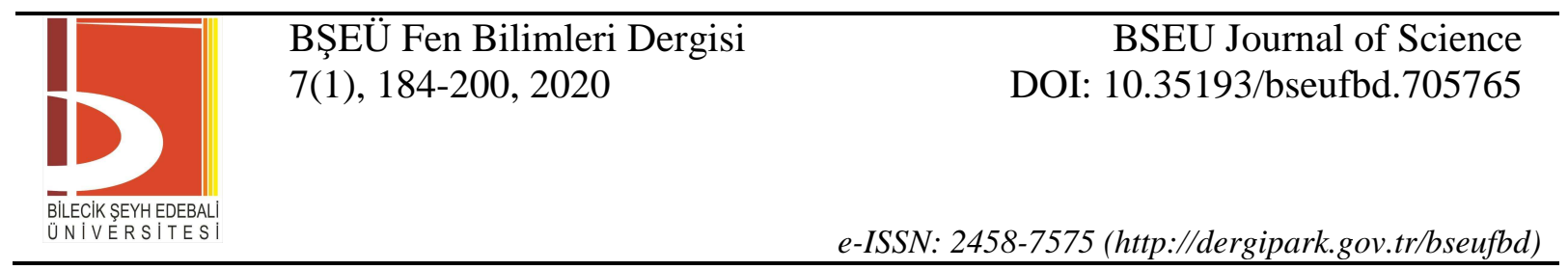

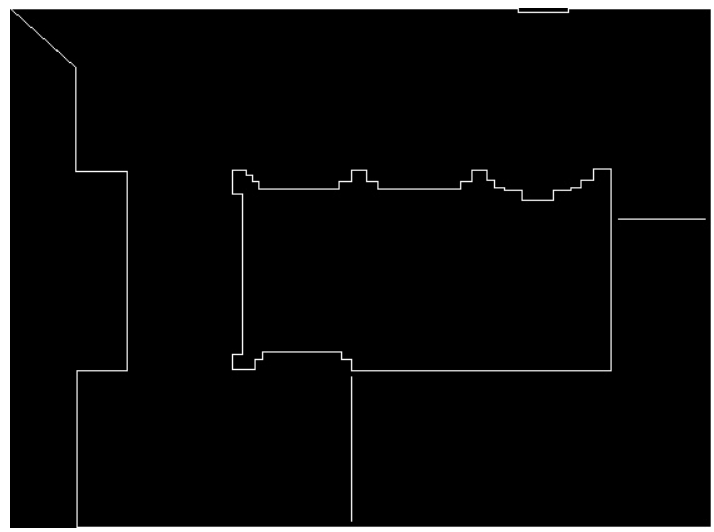

Şekil 12. 2 boyutlu kat krokisi

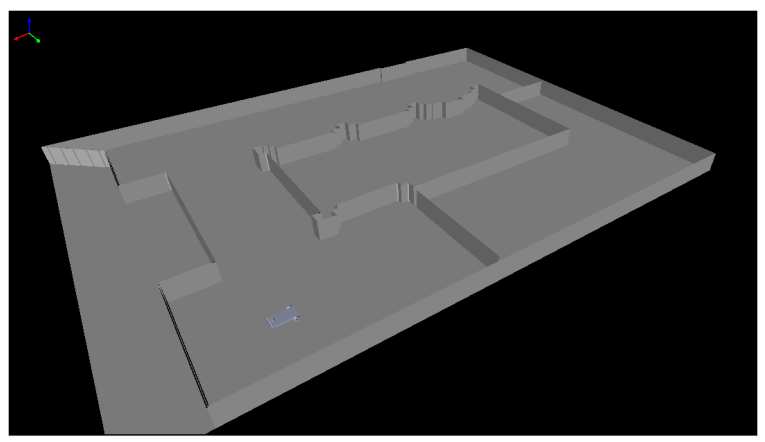

Şekil 13. 3 boyutlu modellenen kat haritası

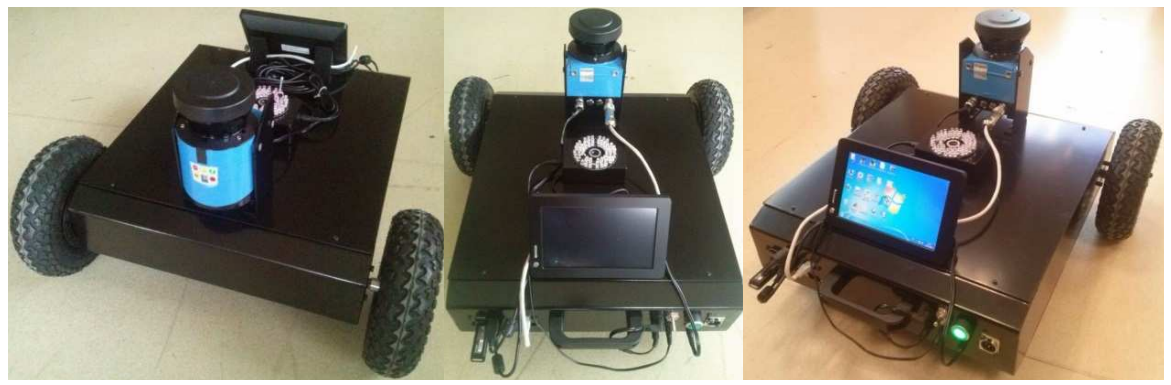

Şekil 14. Fiziksel mobil robot [17]

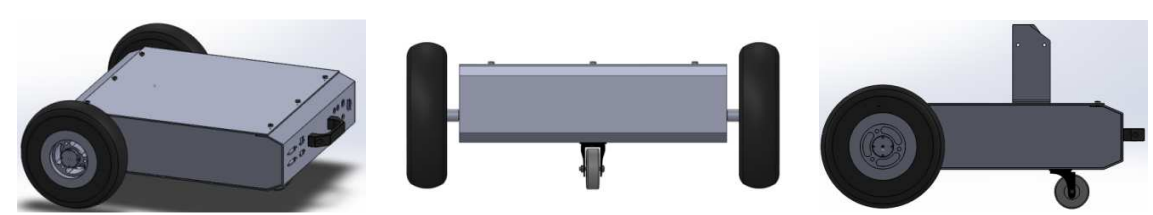

Şekil 15. Uzak istasyonda robotu izlemek için gerçekleştirilen 3 boyutlu tasarım [17]

Açısal kontrol işleminin temel bileşeni olan sanal garaj eklentisi mobil robotun hedef oryantasyonuna istenilen açıda konumlandırılabilmesi için global haritaya statik bir engel olarak eklenmiştir. Sanal garaj kafes biçiminde ve robotun belli bir toleransta sığabileceği boyutlarda tanımlanmıştır. Bu aşamada robotun alternatif yol planlama opsiyonları engellenerek kontrollü bir yörünge üzerinde hedef konumuna istenilen açıda yerleşmesi 


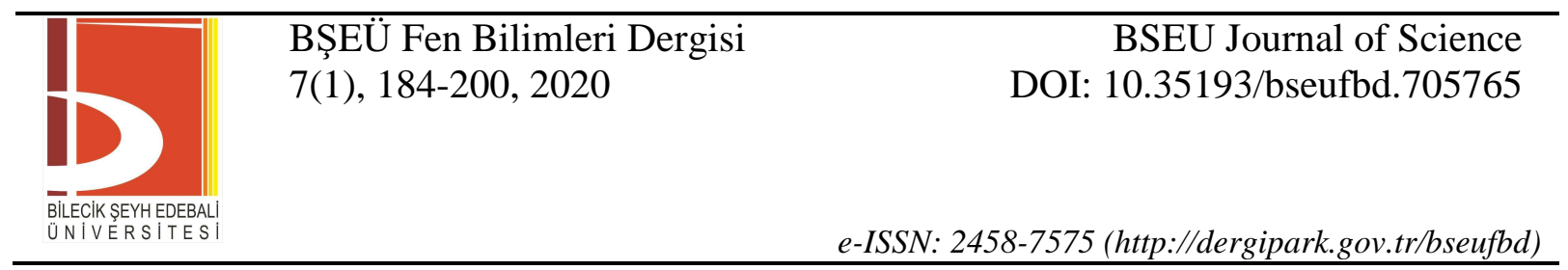

sağlanmaktadır. Örnek bir benzetim uygulamasının başlangıç ve hedef konumlarındaki açısal duruş çıktıları sırasıyla Şekil 16 ve Şekil 17' de verilmiştir.

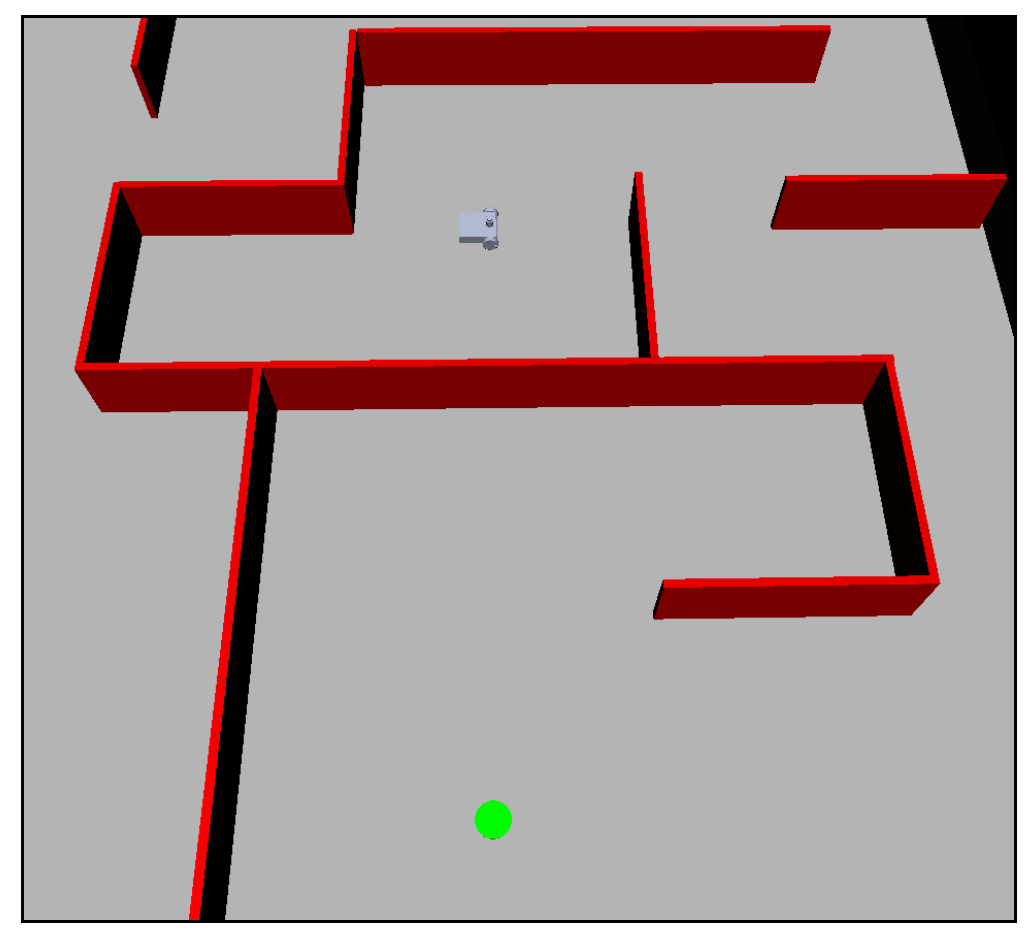

Şekil 16. DWA açısal kontrol benzetim uygulaması: başlangıç

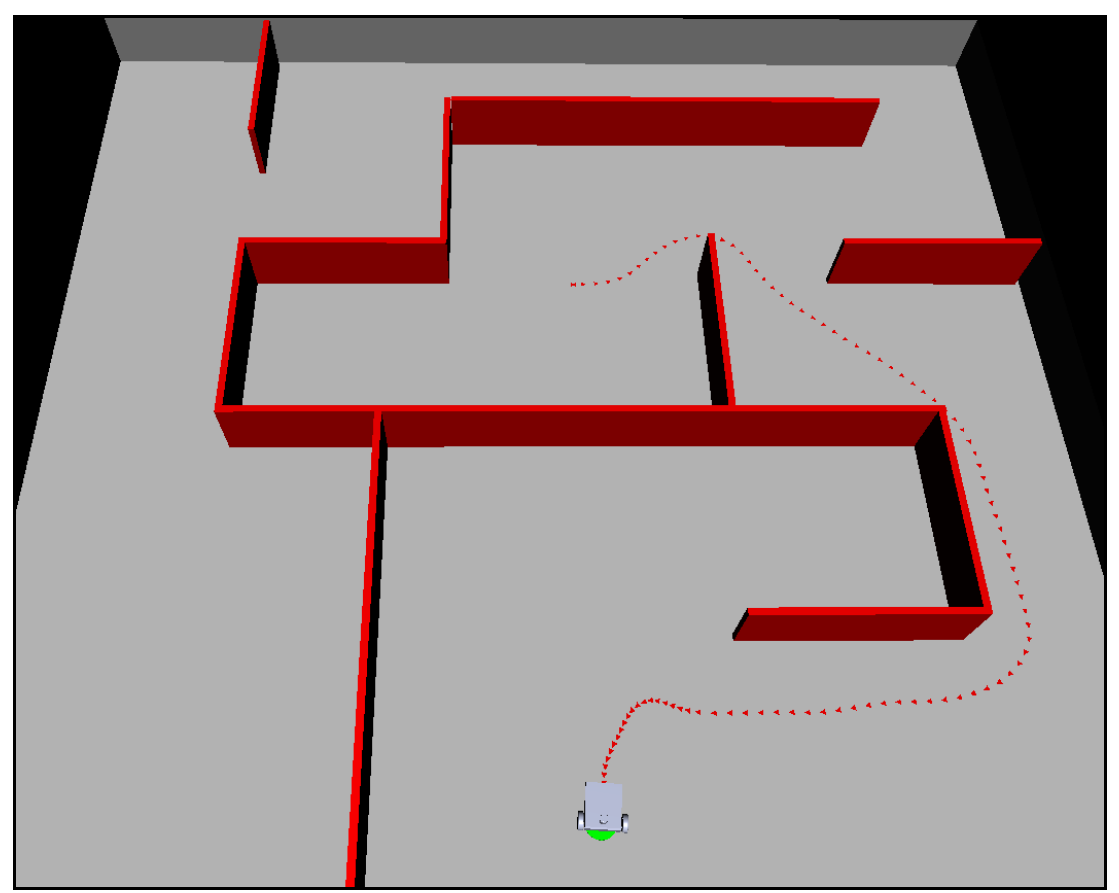

Şekil 17. DWA açısal kontrol benzetim uygulaması: hedef konumu 


\begin{tabular}{|c|c|c|}
\hline & $\begin{array}{l}\text { BŞEÜ Fen Bilimleri Dergisi } \\
7(1), 184-200,2020\end{array}$ & $\begin{array}{l}\text { BSEU Journal of Science } \\
\text { DOI: } 10.35193 / \text { bseufbd } 705765\end{array}$ \\
\hline & & 58-7575 (http://dergipark.gov.tr/bseufbd) \\
\hline
\end{tabular}

Başlangıç konumunda gösterilen robot için verilen hedefin konumu daire olarak gösterilmiştir. Duvar biçimindeki engeller 3 boyutlu olarak gösterilmiştir. Robotun başlangıç oryantasyon açısı $0^{\circ}$, hedef konumundaki istenilen açısı ise $270^{\circ}$ olarak tanımlanmıştır. Hedef konumundaki açısal sapma $2.4^{\circ}$ olarak belirlenmiştir. Sanal garajın global engel haritasında görüntüsü Şekil 18'te verilmiştir. Gri tonlu pikseller serbest alanları, beyaz pikseller engellenmiş bölgeleri göstermektedir. Açısal kontrol uygulamasında sanal garaj eklentisinin etkisi 2 boyutlu statik harita üzerinde görülebilmektedir. Benzetim ortamında yapılan uygulamada açısal kontrol uygulanmaması durumunda robot verilen hedefe belli bir tolerans ölçüsünde yaklaştığı durumda hedefe ulaşıldığ 1 kabul edilmiştir.

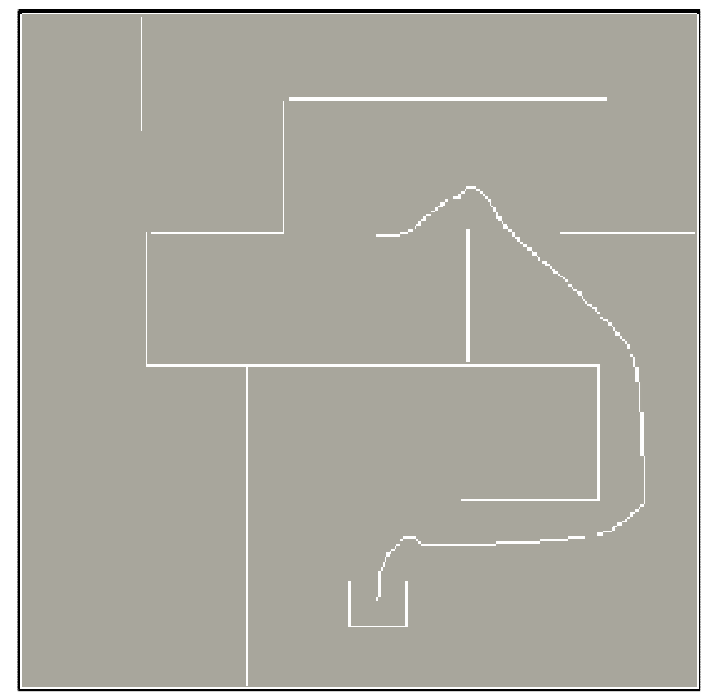

Şekil 18. Açısal kontrol uygulaması: statik harita

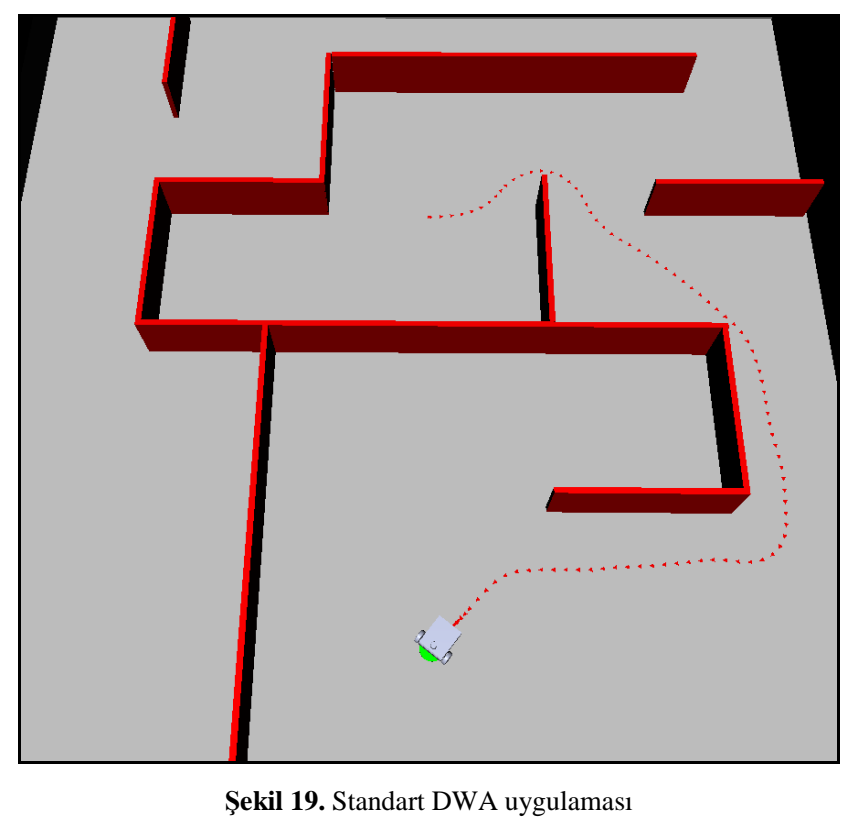

Açısal duruş kontrolünün uygulanmadığı durumda ise nihai konuma yaklaşım ve hedef pozisyondaki duruş açıları planlanamamaktadır. Hedefe yaklaşım açısı robotun anlık duruş açısına bağlı olarak rasgele bir değer olmaktadır. Bu durumun 3 boyutlu arayüz üzerinde gösterimi Şekil 19'te verilmiştir. Statik planlayıcı 


\begin{tabular}{|c|c|c|}
\hline & $\begin{array}{l}\text { BŞEÜ Fen Bilimleri Dergisi } \\
7(1), 184-200,2020\end{array}$ & $\begin{array}{l}\text { BSEU Journal of Science } \\
\text { DOI: } 10.35193 / \text { bseufbd } 705765\end{array}$ \\
\hline & & 58-7575 (http://dergipark.gov.tr/bseufbd) \\
\hline
\end{tabular}

tarafından planlanan yol Şekil 20'de verilmiştir. Sanal garaj uygulanmayan bu durum sadece global hedefe olan Öklid uzaklığını baz alan standart DWA yönteminin yol planlama çıktısını göstermektedir.

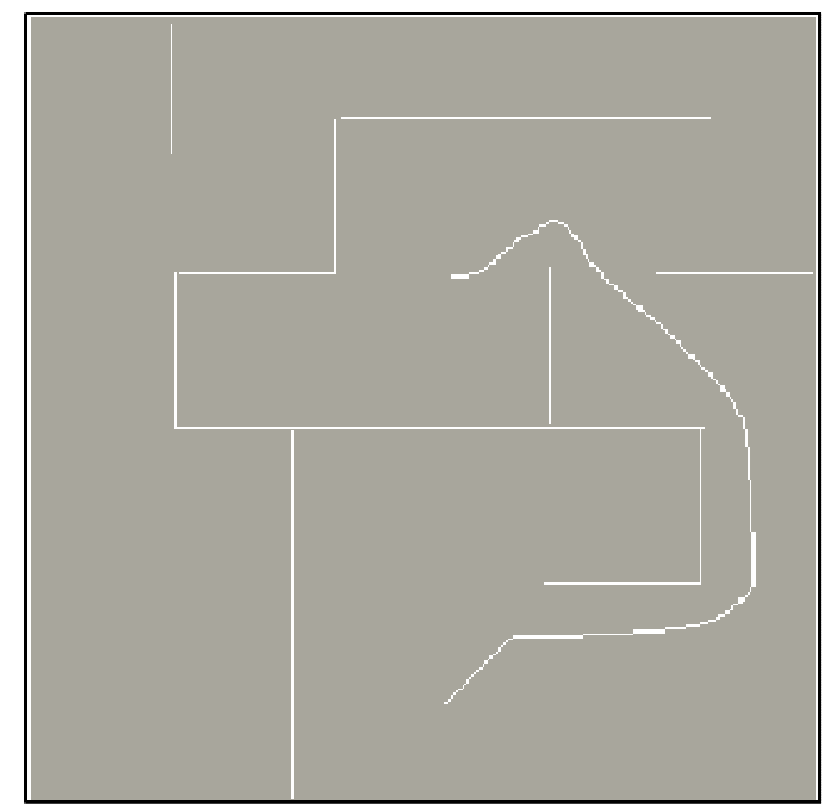

Şekil 20. Standart DWA uygulaması: statik harita

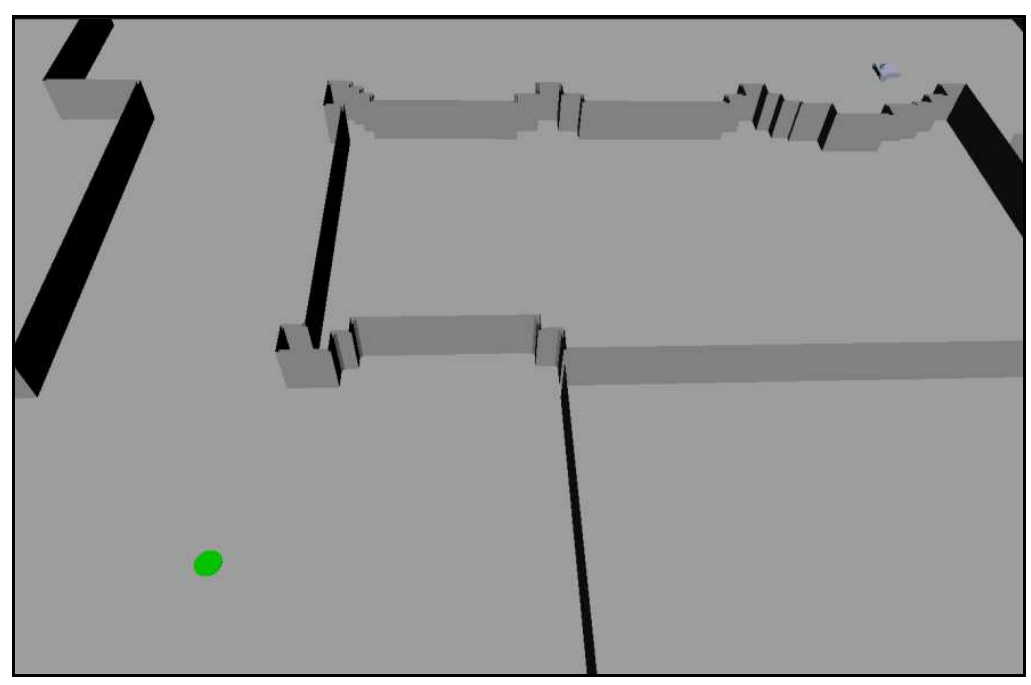

Şekil 21. Açısal kontrol senaryosu: başlangıç konumu

Açısal kontrol yöntemi ile ilgili bir başka senaryo Şekil 21'de verilen benzetim arayüzünde gösterilmiş̧ir. Başlangıç duruş açısı $180^{\circ}$ olan robot için hedef konumunda sahip olması istenen açı $100^{\circ}$ olarak belirlenmiş̧tir. Sanal garaj yapısındaki engel hedef koordinatlarına verilen açıda yerleştirerek, statik yol planlayıcının hedeflenen açıda sonlanan bir referans yörünge planlaması sağlanmıştır. Navigasyon işleminin bitişi ile elde edilen 3 boyutlu görünüm ve 2 boyutlu global engel haritası sırasıyla Şekil 22 ve Şekil 23’te verilmiştir. Hedef konumundaki açısal hata $1.53^{\circ}$ olarak belirlenmiştir. Benzetim arayüzünde 3 boyutlu olarak gösterilen haritada hedefe yaklaşan mobil robotun sanal garaja girerek istenilen açıda belli bir hata ölçüsü ile hedefe konumlandığg görülmektedir. 


\begin{tabular}{|c|c|c|}
\hline & $\begin{array}{l}\text { BŞEÜ Fen Bilimleri Dergisi } \\
7(1), 184-200,2020\end{array}$ & $\begin{array}{r}\text { BSEU Journal of Science } \\
\text { DOI: } 10.35193 / \text { bseufbd. } 705765\end{array}$ \\
\hline $\begin{array}{l}\text { BlLECIKSEYHEDEBAL } \\
\text { UNIVERSITESI }\end{array}$ & & 58-7575 (http://dergipark.gov.tr/bseufbd) \\
\hline
\end{tabular}

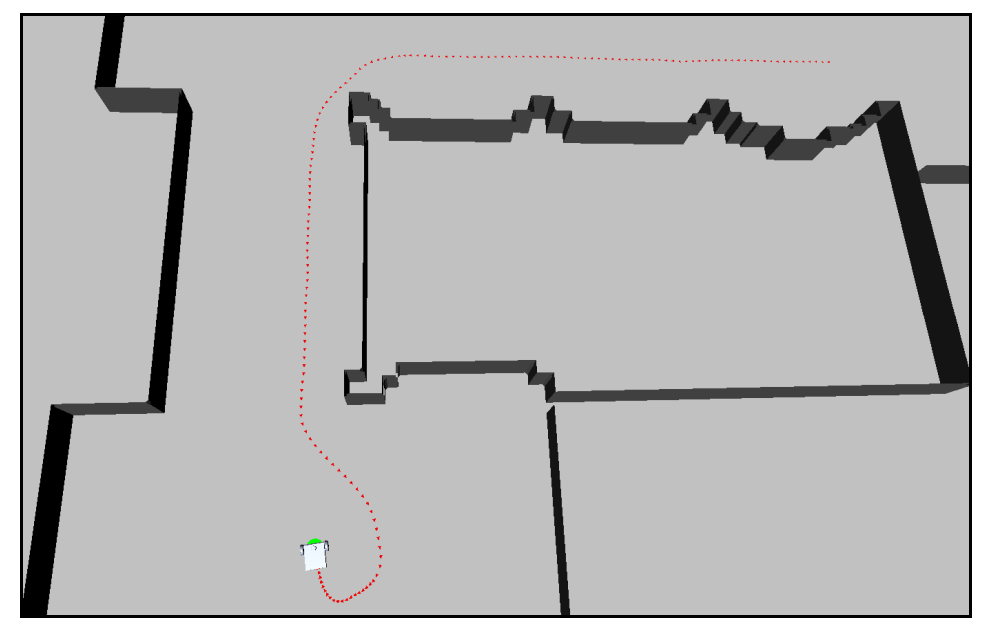

Şekil 22. Açısal kontrol senaryosu: hedef konumu ve oryantasyonu

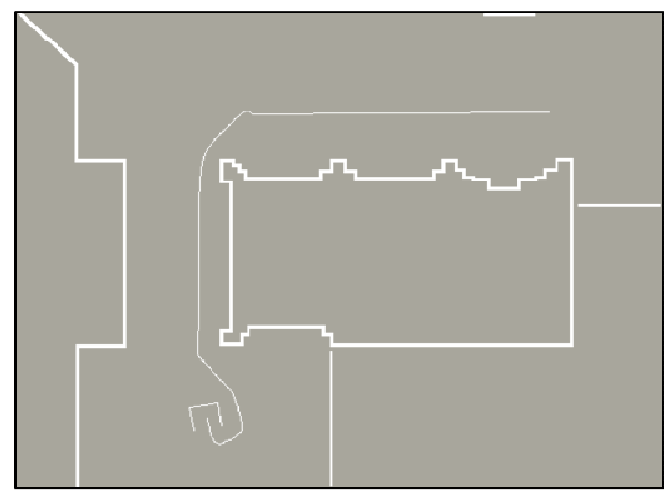

Şekil 23. Açısal kontrol uygulaması: statik harita

Verilen uygulamalarda meydana gelen açısal hatalar sırasıyla $2.40^{\circ}$ ve $1.53^{\circ}$ olarak gözlemlenmiştir. Benzer senaryolar çeşitli başlangıç-hedef konfigürasyonları için uygulanmış, ancak makalenin ilgili görsellerle aşırı uzun tutulmaması adına açısal duruş hataları Tablo 2'de paylaşılmıştır.

Tablo 2. Açısal duruş hataları

\begin{tabular}{cc}
\hline \# Uygulama & Açısal Hata (derece) \\
\hline 1 & 2.40 \\
2 & 1.53 \\
3 & 2.03 \\
4 & 1.66 \\
5 & 1.51 \\
6 & 1.92 \\
7 & 2.54 \\
8 & 2.06 \\
9 & 2.15 \\
10 & 2.21 \\
\hline
\end{tabular}




\section{SONUÇ VEÖNERILER}

Açısal kontrol işleminin temel bileşeni olan sanal garaj eklentisi mobil robotun hedef oryantasyonuna istenilen açıda konumlandırılabilmesi için global haritaya statik bir engel olarak eklenmiştir. Sanal garaj kafes biçiminde ve robotun belli bir toleransta sığabileceği boyutlarda tanımlanmıştır. Bu aşamada robotun alternatif yol planlama opsiyonları engellenerek kontrollü bir yörünge üzerinde hedef konumuna istenilen açıda yerleşmesi sağlanmaktadır. Verilen uygulamalarda oluşan statik haritalar incelendiğinde, yörünge üzerinde süreksizlik arz eden geçişler gözlemlenebilmektedir. Bu durum imge olarak gösterilen haritada $\mathrm{cm} /$ piksel çözünürlügünün düşük tutulmasından kaynaklanmaktadır. Daha geniş fiziksel alanları görselleştirmek için ideal bir ölçeklendirme olarak $5 \mathrm{~cm} \equiv 1$ piksel kabulü yapılmıştır. Bu çözünürlük, yaklaşık $30 \mathrm{~m}$ x 30m fiziksel genişliğe karşlık gelen haritaları görselleştirmek için kabul edilen dönüşümdür.

Yapılan çalışma DWA metodu ile ilgili literatürde açık olan açısal duruş kontrolüne bir çözüm olarak verilmiştir. Konumlama hassasiyeti ile doğrudan ilgili olan yöntem, gerçek zamanlı ek güvenlik sensör donanımları veya benzetim modelleri uygulanarak güvenlik seviyesi ileri aşamalara taşınabilir. Arama uzayını daraltmak için global planlayıcı olarak A* planlama şeması uygulanabilir [18].

\section{KAYNAKLAR}

[1] Dugarjav, B., Kim, H. \& Lee, H. (2015). Online Cell Decomposition with a Laser Range Finder for Coverage Path in an Unknown Workspace. International Journal of Mechanical And Production Engineering, 3, 18-24.

[2] Fahad, I., Jauwairia, N., Usman, M., Yasar, A. \& Osman, H. (2012). RRT-Smart: Rapid Convergence Implementation of RRT* Towards Optimal Solution. 2. IEEE International Conference on Mechatronics and Automation (ICMA). Ağustos, Çin, 1651-1656.

[3] Wang, J., Wu, S., Li, H. \& Zou, J. (2018). Path Planning Combining Improved Rapidly-Exploring Random Trees with Dynamic Window Approach in ROS. IEEE Conference on Industrial Electronics and Applications (ICIEA). Temmuz, Çin, 1296-1301.

[4] Firas, R. \& Mustafa, M. (2017). Development of Modified Path Planning Algorithm Using Artificial Potential Field (APF) Based on PSO for Factors Optimization. American Scientific Research Journal for Engineering, Technology, and Sciences, 37, 316-328.

[5] Siméon, T., Laumond, J. \& Nissoux, C. (2000). Visibility-Based Probabilistic Roadmaps for Motion Planning. Journal of Advanced Robotics, Technology, 14, 477-493.

[6] Özdemir, A. \& Sezer, V. (2018). Follow the Gap with Dynamic Window Approach. International Journal of Semantic Computing, 12, 43-57.

[7] Borenstein, J., Koren, Y. (1991). The Vector Field Histogram-Fast Obstacle Avoidance for Mobile Robots. IEEE Trans. Robot. Autom, 7, 278-288.

[8] Sezer, V. \& Gokasan, M. (2012). A Novel Obstacle Avoidance Algorithm: Follow the Gap Method. Robot. Auton. Syst, 60, 1123-1134.

[9] Marin, P., Hussein, A., Martin, D. \& Escalera, A. (2018). Global and Local Path Planning Study in a ROSBased Research Platform for Autonomous Vehicles. Journal of Advanced Transportation, 60, 1-10.

[10] McNaughton, M., Urmson, C., Dolan, M. \& Lee, J. (2018). Motion Planning for Autonomous Driving with a Conformal Spatiotemporal Lattice. IEEE International Conference on Robotics and Automation. May1s, Çin, 4889-8995.

[11] Guoyang, L., Genxia, W. \& Wei, W. (2006). ND-DWA: A Reactive Method for Collision Avoidance in Troublesome Scenarios. World Congress on Intelligent Control and Automation. Haziran, Çin, 9307-9311. 
[12] Fox, D., Burgard, W. \& Thrun, S. (1997). The Dynamic Window Approach to Collision Avoidance. IEEE Robotics and Automation Magazine, 4, 23-33.

[13] Furrer, F., Burri, M., Achtelik, M. \& Siegwart, R. (2016). Robot Operating System (ROS). Springer International Publishing, İsviçre, 74-78.

[14] Dongkai, F. \& Shi, P. (2010). Improvement of Dijkstra's algorithm and Its Application in Route Planning. IEEE Journal of Oceanic Engineering, 13, 1901-1904.

[15] Stephen, B. \& Lieven, V (2004). Unconstrained Minimization Convex Optimization. Cambridge University Press, New York, 457-458.

[16] Karakaya, S., Küçükyıldız, G. \& Ocak, H (2017). A New Mobile Robot Toolbox for MATLAB. J Intell Robot Syst, 87, 125-140.

[17] Karakaya S. \& Ocak, H. (2019). Design and Implementation of a Wheeled Mobile Robot Platform. International Conference on Image Processing, Wavelet and Applications. Ekim, Türkiye, 1-9.

[18] Gopikrishnan, S., Shravana, S., Harshit G., Barve, P. \& Ravikumar L (2011). Path Planning Algorithms: A Comparative Study. National Conference on Space Transportation Systems. Aralı, Hindistan, 1-8. 